\title{
Effect of Coronavirus Disease 2019 on $\mathrm{CO}_{2}$ Emission in the World
}

\author{
Sahar Safarian*, Runar Unnthorsson, Christiaan Richter \\ Faculty of Industrial Engineering, Mechanical Engineering and Computer Science, University of Iceland, 107 Reykjavik, \\ Iceland
}

\begin{abstract}
In order to decrease spreading of Coronavirus disease 2019 (COVID-19) over the world, the activity of many industries has declined, several flights were cancelled and so many people staying home that made drop in fuel consumption in road transport. As industries, transport networks and businesses have closed down, it has brought a sudden drop in carbon emissions. Hence, in this paper, a simple estimation model is developed by using some excel features to assess the reduced $\mathrm{CO}_{2}$ emissions in March 2020. Then this indicator is calculated for 3 scenarios which are based on this disease situation worldwide and therefore based on different reduction percent of fossil fuels consumption in various sectors over year 2020. In scenario 1, it is assumed the number of infected people increasing but it is before peak region. In this zone, the measures to slow the rate of infection would be similar till end of year. In scenario 2, the infectious growth rate in the world reaches to peak region. Hence, the protective measures would be extended. As a result, industries activities and various kinds of transportations will be probably reduced much more in comparison with scenario 1 . In scenario 3, it is assumed the growth rate begins to fall and it is after peak region. In this zone, the intervention and protective measures would be lessened toward scenario 1. So, industries activities and transportations will be likely increased in compare to other scenarios. The results show that $\mathrm{CO}_{2}$ emissions worldwide in March 2020 has been 7\% lower than the monthly average of this parameter in 2019 as consequence of COVID-19. Moreover, carbon emission through 2020 has been estimated to be 34.4, 32.4 and 35.3 Gton based on scenarios 1, 2 and 3, respectively. It is worth to mention that based on these three scenarios, this indicator in 2020 will be approximately the same as 2011, 2008 and 2012.
\end{abstract}

Keywords: COVID-19; $\mathrm{CO}_{2}$ emission; Industries; Road transport; Aviation transport.

\section{INTRODUCTION}

In early 1700 s from the beginning of the industrial revolution, the burning fossil fuel as one of the most important human activities, releases Carbon dioxide to the atmosphere. Especially during the last three decades, $\mathrm{CO}_{2}$ emission and the average temperature in the world have been growing hugely. The global warming has been introduced as a main issue caused by $\mathrm{CO}_{2}$ emission that all countries face on, no matter the countries are economically developed or not (Kwon, 2017). Many studies confirm that $\mathrm{CO}_{2}$ emissions caused by human activities cause directly increases of the global temperature (Boden et al., 2009; Shakun et al., 2012). In other words, according to the Intergovernmental Panel on Climate Change's (IPCC), human's emissions and activities have caused around $100 \%$ of the warming observed since 1950 (IPCC, 2013).

The contribution of each of various sources (gas, liquid

\footnotetext{
* Corresponding author.

E-mail address: sas79@hi.is
}

(i.e., oil), solid (coal and biomass), flaring, and cement production) on $\mathrm{CO}_{2}$ emission in different years is shown in Fig. 1. Clearly, Fig. 1 shows that carbon emission was increasing sharply through years and it was dominated by using of solid fuel. Coal-fired power at industrial scales firstly emerged in Europe and North America during the 1700 s. It wasn't until the late 1800 s that it began to see a growth in emissions from oil and gas production. Another century passed before emissions from flaring and cement production began. However, solid and liquid fuel are still dominating contributions (Ritchie and Roser, 2019).

Based on some researches like (Hansen et al., 1981), from 1960s till the recent time, the global mean temperature has been constantly increased by $0.2^{\circ} \mathrm{C}$ in each decade. The study directed by IPCC (IPCC, 2007) illustrates that average temperature globally during the last 100 years has been raised by $0.74^{\circ} \mathrm{C} \pm 0.18^{\circ} \mathrm{C}$ from 1906 to 2005 . According to this study, temperature changes over the last 25 years (19812005), 50 years (1956-2005), 100 years (1906-2005), 150 years $(1856-2005)$ are $0.18^{\circ} \mathrm{C} \pm 0.05^{\circ} \mathrm{C}, 0.13^{\circ} \mathrm{C} \pm$ $0.03^{\circ} \mathrm{C}, 0.07^{\circ} \mathrm{C} \pm 0.02^{\circ} \mathrm{C}$ and $0.05^{\circ} \mathrm{C} \pm 0.01^{\circ} \mathrm{C}$, respectively. To compare, temperature changes within last 25 years are almost four times greater than its changes during the last 


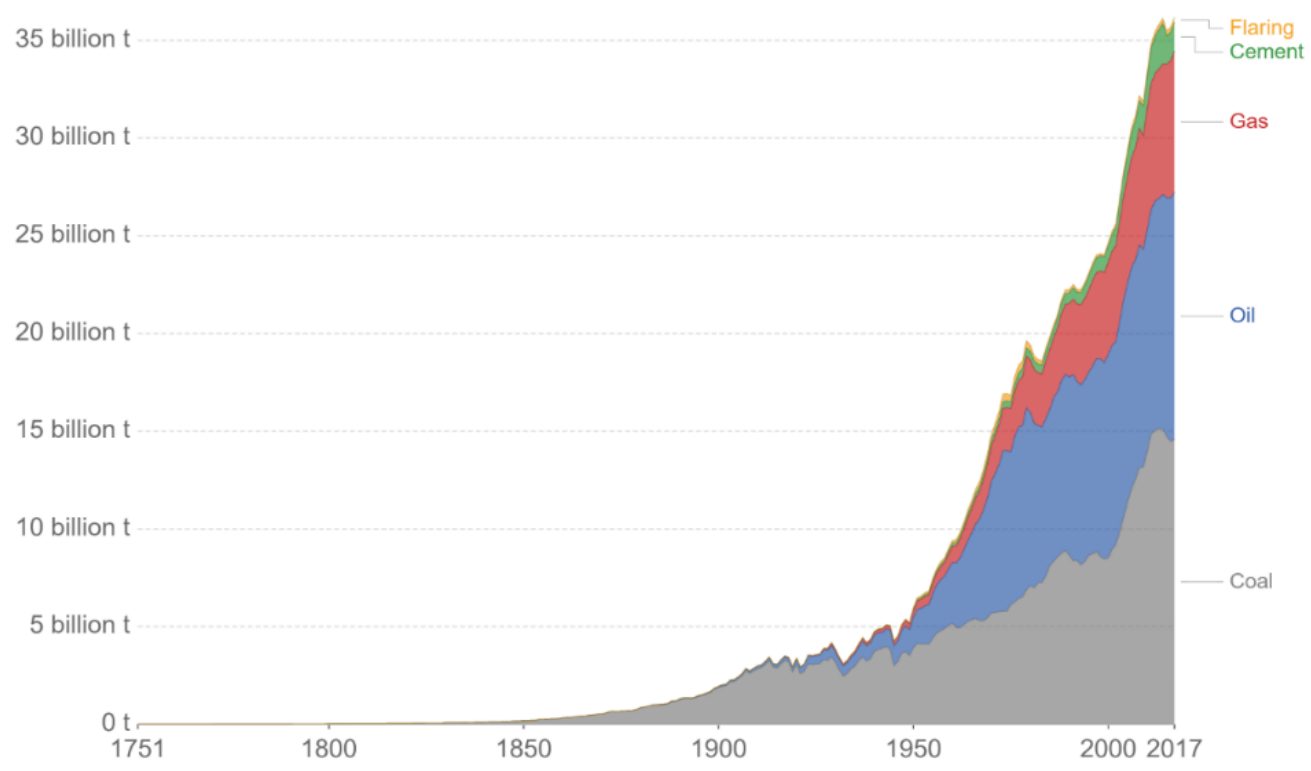

Fig. 1. $\mathrm{CO}_{2}$ emissions by fuel type in the world.

150 years and average temperature changes over the last 50 years are almost twice larger in comparison to its changes during the last 100 years. Therefore, the global mean temperature increases more rapidly within the shorter period.

It was projected that $\mathrm{CO}_{2}$ emissions in the world will increased till 2020 and it reaches to around 37 billion ton (Mearns, 2018). However, carbon emissions have decreased through the past months (Jan-April 2020). In recent months, thousands of people have died and hundreds of thousands more have fallen ill from a Coronavirus disease 2019. Hence, to control the spread of this virus, most of travels have been restricted, so many public places were closed, extensive flights were cancelled and so many industries have closed down in the world. As a result of these events, level of pollution and greenhouse gas emissions have fallen across continents (BBC, 2020). Hence firstly in this work, we aim to estimate the amount of reduction in $\mathrm{CO}_{2}$ emission worldwide through March 2020 and then evaluate the reducing $\mathrm{CO}_{2}$ emissions through the year 2020, based on 3 scenarios with different reduction percent of fuels consumption.

\section{METHODS}

The amount of reduction in $\mathrm{CO}_{2}$ emission globally through March 2020 can be calculated by using Eq. (1) (Safarian et al., 2018, 2019):

$\Delta D_{\mathrm{CO}_{2}}=\sum_{j} \sum_{i} \Delta F_{i j} \times \alpha_{i}$

$$
\Delta F_{i j}=F_{i j} \times r_{i j}
$$

$\Delta_{\mathrm{CO}_{2}}$ is the amount of $\mathrm{CO}_{2}$ emission reduction that is caused due to reduce in the consumption of different fuels (i) in different sectors (j) (GreenCarCongress, 2014; EIA,
2016; Knoema, 2017; Statisca, 2020), $\left(\Delta F_{i j}\right)$. In fact, decreasing in $\mathrm{CO}_{2}$ emissions are due to declining in fuels consumption like jet fuel in aviation transport, gasoline and diesel in road transport and liquid fuel, coal, natural gas and electricity in industrial sectors. $\alpha_{i}$ is also the emission factor of $\mathrm{CO}_{2}$ per unit consumption of different fuels (EIA, 2019, 2020). $\Delta F_{i j}$ is calculated by using Eq. (2) that in which, $r_{i j}$ is reduction percent of various fuels in different sectors. The amount of fuels consumption, their reduction percent during March 2020 and their $\mathrm{CO}_{2}$ emission factors are shown in Table 1 (GreenCarCongress, 2014; EIA, 2016; Knoema, 2017; EIA, 2019, 2020; RYSRADENERGY, 2020; Statisca, 2020).

Actually, in this work, we estimate the reduction of $\mathrm{CO}_{2}$ emission in the transport sector (aviation and road) and the industrial sector (electricity included) and do not consider the residential, commercial and agricultural sectors due to the below reasons:

1. Carbon dioxide enters the atmosphere through burning fossil fuels (coal, natural gas, and oil), solid waste, trees and other biological materials, and also as a result of certain chemical reactions (e.g., manufacture of cement). However, the largest source of greenhouse gas emissions from human activities in the world is from burning fossil fuels for electricity, heat, and transportation.

2. Fig. 2, shows the global fossil fuel consumption by various sectors in 2017 (EnergyPost, 2019). As it is observed in Fig. 2, around $90 \%$ of fossil fuel is consumed in Industrial sector (including industries and power plants) and transport sector (road and aviation transports) and lower than $10 \%$ of oil, gas and coal are consumed in other sectors.

3. The global $\mathrm{CO}_{2}$ emission by various sectors in 2019 is shown in Fig. 3 (Krum, 2019). As it is observed from Fig. 3, the huge amount of $\mathrm{CO}_{2}$ (approximately 70\%) is emitted through the transport (road and aviation transports) and industrial sectors (including industries and power 
Table 1. The amount of fuels consumption, their reduction percent during March 2020 and their $\mathrm{CO}_{2}$ emission factors.

\begin{tabular}{|c|c|c|c|c|c|c|}
\hline & Fuels & $\begin{array}{l}\text { Recent } \\
\text { consumption }\end{array}$ & Unit & $\begin{array}{l}\text { Reduction } \\
\text { percent }\left(r_{i j}\right)\end{array}$ & $\begin{array}{l}\mathrm{CO}_{2} \text { emission } \\
\text { factors }\left(\alpha_{i}\right)\end{array}$ & Unit \\
\hline Aviation Transport & Jet fuel & 13.14 & Mton month ${ }^{-1}$ & 20 & 3.16 & $\mathrm{~kg}_{\mathrm{CO} 2} / \mathrm{kg}_{\text {fuel }}$ \\
\hline \multirow[t]{2}{*}{ Road Transport } & Gasoline & 3.75 & Quadrillion Btu month ${ }^{-1}$ & 10 & 157.2 & $\mathrm{Lb}_{\mathrm{CO} 2} / \mathrm{MBtu}$ \\
\hline & Diesel & 1.25 & Quadrillion Btu month ${ }^{-1}$ & 10 & 161.3 & $\mathrm{Lb}_{\mathrm{CO} 2} / \mathrm{MBtu}$ \\
\hline \multirow[t]{4}{*}{ Industries } & Liquid fuel & 5.2 & Quadrillion Btu month ${ }^{-1}$ & 10 & 161.3 & $\mathrm{Lb}_{\mathrm{CO} 2} / \mathrm{MBtu}$ \\
\hline & Coal & 5.3 & Quadrillion Btu month $^{-1}$ & 10 & 228 & $\mathrm{Lb}_{\mathrm{CO} 2} / \mathrm{MBtu}$ \\
\hline & Natural gas & 4.6 & Quadrillion Btu month ${ }^{-1}$ & 10 & 117 & $\mathrm{Lb}_{\mathrm{CO} 2} / \mathrm{MBtu}$ \\
\hline & Electricity & 3.05 & Quadrillion Btu month ${ }^{-1}$ & 10 & 0.99 & $\mathrm{Lb}_{\mathrm{CO} 2} / \mathrm{MBtu}$ \\
\hline
\end{tabular}

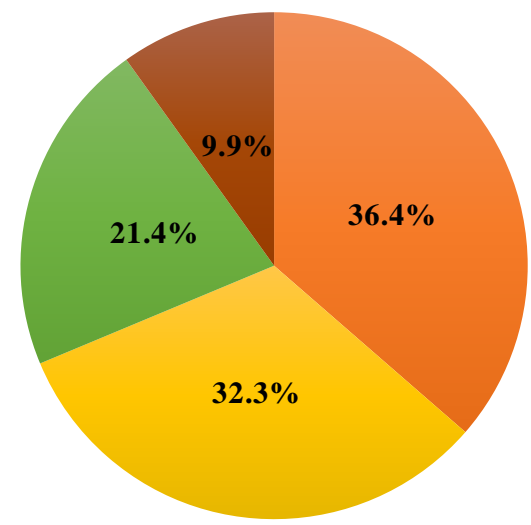

$\square$ Electricity $\square$ Transport $\square$ Industries $\quad$ Other (e.g. residential, commercial)

Fig. 2. Global fossil fuel consumption by sectors in 2017.

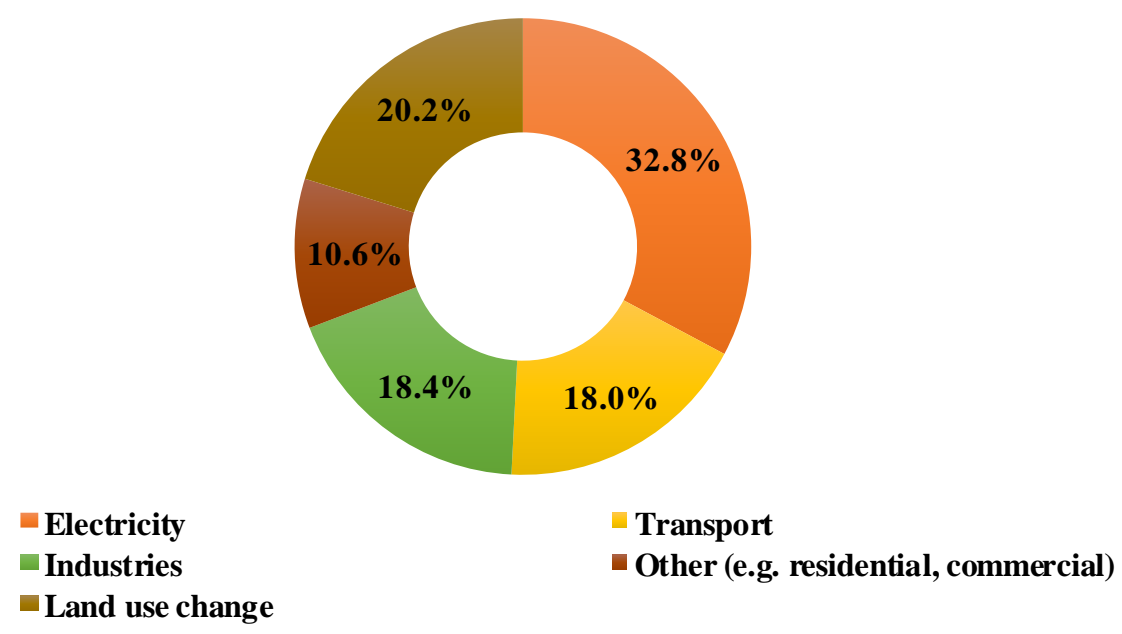

Fig. 3. Global $\mathrm{CO}_{2}$ emission by sectors in 2019.

plants). Only $10 \%$ of $\mathrm{CO}_{2}$ emission is due to fossil fuel burning in residential and commercial sectors and $20 \%$ $\mathrm{CO}_{2}$ releasing to the atmosphere is because of land use of change (e.g. agriculture, forestry and any other land use change).

4. It was mentioned in the first and the second points that the fossil fuel consumption and $\mathrm{CO}_{2}$ emission through the residential, commercial and agricultural sectors are much less than transport and industrial sectors. Moreover based on the news, the huge reduction of fossil fuel consumption (as a result of Coronavirus disease 2019) happed in industries, power plants and transportation. For example, the streets of Wuhan, China, are deserted after authorities implemented a strict lockdown. In Italy, the most extensive travel restrictions are in place since World War Two. In London, the normally bustling pubs, bars and theatres have been closed and people have been told to stay in their homes. Worldwide, flights are being cancelled or turning around in mid-air, as the aviation industry buckles. Those who are able to do so are holed 
up at home, practicing social distancing and working remotely. It is all aimed at controlling the spread of COVID-19, and hopefully reducing the death. But all this change has also led to some unexpected consequences. As industries, transport networks and businesses have closed down, it has brought a sudden drop in carbon emissions (BBC, 2020). In addition, there are some data about reduction in fossil fuel consumption in different industries and various kinds of transportation but we could not find any data about this indicator for other sectors.

Based on prediction model developed by researchers from Singapore University of Technology (BioTechniques, 2020), COVID-19 will end on the worldwide scale of around 4 December. However, it is different for various countries, for Singapore predicted to be around 28 June, for UK to be around 27 August and the USA will be around 20 September. Although prediction is relied on science and data, it is possible its results change, because the data provided, the model and prediction could be inaccurate and insufficient to fully represent the complexity of realities in the world (BioTechniques, 2020). Hence, everything can be happening that getting better or worse Coronavirus disease 2019 through the year.

In order to estimate reducing $\mathrm{CO}_{2}$ emissions through the year 2020, in this work we investigate three scenarios based on the situation of Coronavirus disease 2019. The bellshaped curve of COVID-19 on worldwide scale is shown in Fig. 4. The different area of scenario 1, 2 and 3 are also depicted on Fig. 4. The orange area represents scenario 1 that it is assumed the number of infected people increasing but it is before peak region. In this zone, the measures to slow the rate of infection would be similar to March till end of year 2020. The red area displays scenario 2 that is assumed the infectious growth rate in the world reaches to peak region. Hence, the protective measures to control the spread of this disease would be extended. As a result, industries activities and various kinds of transportations will be probably reduced much more in comparison with scenario 1 . The yellow area shows scenario 3 that is assumed the growth rate begins to fall and the curve changes from an exponential one to a normal distribution or bell curve. In this zone, the intervention and measures to slow the rate of infection would be lessened toward March till end of year 2020. So, industries activities and transportations will be likely increased in compare to scenario 1 and 2 .

According to the above mentioned explanation, the scenarios have different reduction percent of fossil fuels consumption in the considered sectors (Table 2). According to scenario 1, the reduction percent from April to December are similar to March. However, this indicator through the year for scenario 2 is higher than scenario 1 and in scenario 3 it is lower than others.

\section{RESULTS AND DISCUSSION}

The drop amount of $\mathrm{CO}_{2}$ emissions from reduction consumption of different fuels in different sectors were brought in Table 3. Monthly average of $\mathrm{CO}_{2}$ emissions in 2019 worldwide was 3,067.5 Mton (Ritchie and Roser, 2019). However, in March 2020 it shows 7\% reduction compared to the later value as consequence of COVID-19. Indeed, this value is approximately equal to monthly average $\mathrm{CO}_{2}$ emissions in 2011.

Moreover, contributions in $\mathrm{CO}_{2}$ emission reduction in the world were shown in Fig. 5. Obviously, the largest contribution

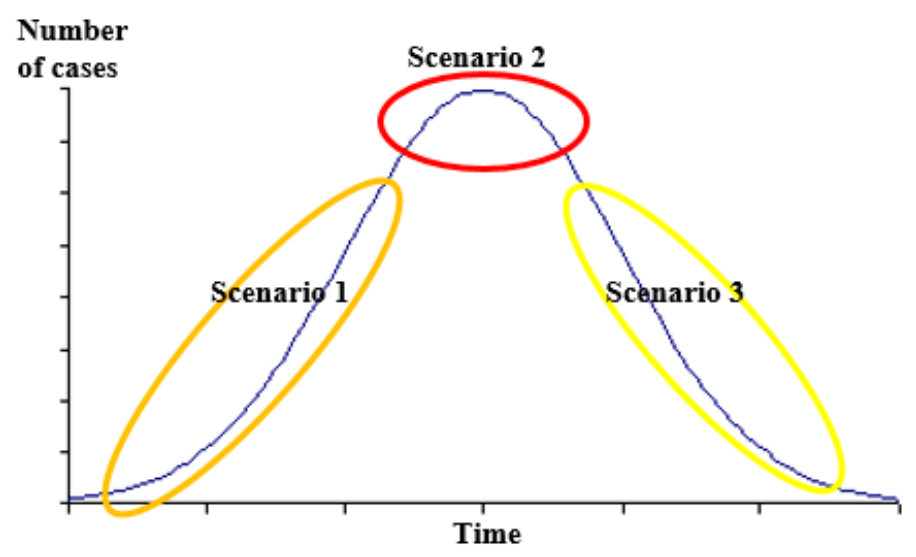

Fig. 4. The bell-shaped curve of COVID-19 in the world and scenarios area.

Table 2. Different reduction percent of fuels for 3 scenarios (\%).

\begin{tabular}{llllllllllllll}
\hline & Jan & Feb & Mar & Apr & May & Jun & Jul & Aug & Sep & Oct & Nov & Dec \\
\hline Scenario 1 & Industries and Road Transport & 5 & 5 & 10 & 10 & 10 & 10 & 10 & 10 & 10 & 10 & 10 & 10 \\
& Aviation Transport & 10 & 10 & 20 & 20 & 20 & 20 & 20 & 20 & 20 & 20 & 20 & 20 \\
Scenario 2 & Industries and Road Transport & 5 & 5 & 10 & 20 & 20 & 20 & 20 & 20 & 20 & 20 & 20 & 20 \\
& Aviation Transport & 10 & 10 & 20 & 30 & 30 & 30 & 30 & 30 & 30 & 30 & 30 & 30 \\
Scenario 3 3 & Industries and Road Transport & 5 & 5 & 10 & 5 & 5 & 5 & 5 & 5 & 5 & 5 & 5 & 5 \\
& Aviation Transport & 10 & 10 & 20 & 10 & 10 & 10 & 10 & 10 & 10 & 10 & 10 & 10 \\
\hline
\end{tabular}


Table 3. Drop in $\mathrm{CO}_{2}$ emissions from different parts.

\begin{tabular}{lll}
\hline & Fuels & $\Delta_{\mathrm{CO}_{2}}\left(\right.$ Mton $\left.\mathrm{month}^{-1}\right)$ \\
\hline Aviation transport & Jet fuel & 8,30 \\
Road Transport & Gasoline & 29,48 \\
& Diesel & 10,08 \\
Industries & Total & 39,56 \\
& Liquid fuel & 41,94 \\
& Coal & 60,52 \\
& Natural gas & 26,96 \\
Total & Electricity & 44,37 \\
& Total & 173,78 \\
\hline
\end{tabular}

\section{Industries Aviation transport $\quad$ Road Transport}

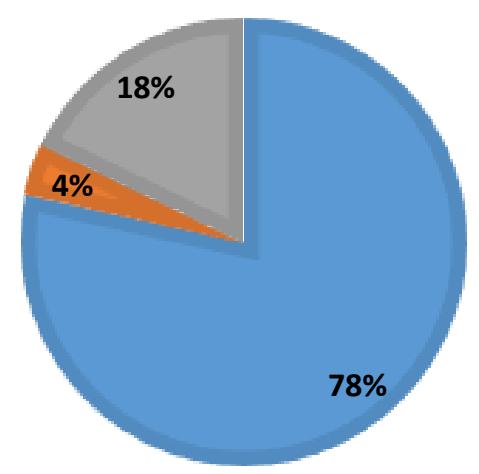

Fig. 5. Contributions in $\mathrm{CO}_{2}$ emission reduction.

is made by industrial sector through decrease in fossil fuels especially coal used over the world, following with road transport and aviation transport.

This carbon reduction has been caused because of Coronavirus disease 2019. It seems that this disease is unstoppable. The virus that has had a fatal impact on people's lives, it is also threatening the industries and transportation over the world. The COVID-19 pandemic effected so much restrictions on public gatherings and on many organized activities and businesses. So it made that many of people staying at home and doing less in terms of social interactions and exercise. Since February 2020, many things have changed and will keep constantly changing due to the coronavirus disease 2019 and its impacts on the transport and industries. There were so much limited export loads and the extra delays of port operations due to the raising of limited transport and lack of transshipment operators and warehousemen. In fact, that the number of goods imported is limited with the shortened routes the transport companies carry out, it will be possible that industries activities and trade level play down as a result of the COVID-19 outbreak. All these changes have also led to some unexpected consequences. As industries, transport networks and businesses have degraded, it has brought a sudden drop in $\mathrm{CO}_{2}$ emissions.

According to scenarios 1,2 and $3, \mathrm{CO}_{2}$ emissions through 2020 is estimated to be decreased around 2,438, 4,395 and 1,440 Mton; these values are around 6.6, 11.9 and 3.9\% reduction in comparison to 2019 , respectively. It is worth to say that based on these scenarios, $\mathrm{CO}_{2}$ emissions in 2020 will be approximately the same as 2011, 2008 and 2012.

Although, the $\mathrm{CO}_{2}$ emission in 2020 for scenarios 1,2 and 3 has been estimated similar to 2011, 2008 and 2012, the share of carbon emissions in different sectors are not the same. The $\mathrm{CO}_{2}$ emission contributions in 2011, 2008 and 2012 were gathered in Table 4 (Ritchie and Roser, 2019). As is clear, approximately $70 \%, 20 \%$ and $10 \%$ of $\mathrm{CO}_{2}$ emission are corresponding to industrial sector (industries and electricity production), transport sector and other (residential, commercial and public services), respectively.

In addition, the $\mathrm{CO}_{2}$ emission shares by various sectors in 2020 for three scenarios were shown in Fig. 6. In the first scenario, the $\mathrm{CO}_{2}$ emission in industrial and transport sectors are $14.3 \%$ and $6 \%$ less than its shares in 2011. In the second scenario, this indicator is about $17.2 \%$ and $7.8 \%$ lower in comparison its values in 2008. In the final scenario, the $\mathrm{CO}_{2}$ emission in industrial and transport sectors is $11.8 \%$ and $5.8 \%$ less than its values in 2012 .

\section{CONCLUSIONS}

In this paper, firstly the reduced $\mathrm{CO}_{2}$ emissions worldwide in March 2020 is estimated. This carbon reduction is due to closing down of industries, transport networks and businesses as consequence of COVID-19. Then this indicator is calculated for 3 scenarios which are based on different reduction percent of various fuels over year 2020. The results show that $\mathrm{CO}_{2}$ emissions worldwide in March 2020 has been $7 \%$ lower than the monthly average of this parameter in 2019 and the largest contribution of this reduction is made by industrial sector through decrease in fossil fuels especially coal used over the world. Moreover, carbon emission through 2020 has been estimated to be 34.4, 32.4 and 35.3 Gton based on scenarios 1, 2 and 3, respectively. It is worth to mention that based on these three scenarios, this indicator in 2020 will be approximately the same as 2011, 2008 and 2012.

Table 4. $\mathrm{CO}_{2}$ emission contributions.

\begin{tabular}{llll}
\hline Sectors & 2011 & 2008 & 2012 \\
\hline Industrial & 69,55 & 67,84 & 69,26 \\
Transport & 19,75 & 20,44 & 20,13 \\
Other & 10,71 & 11,72 & 10,61 \\
\hline
\end{tabular}




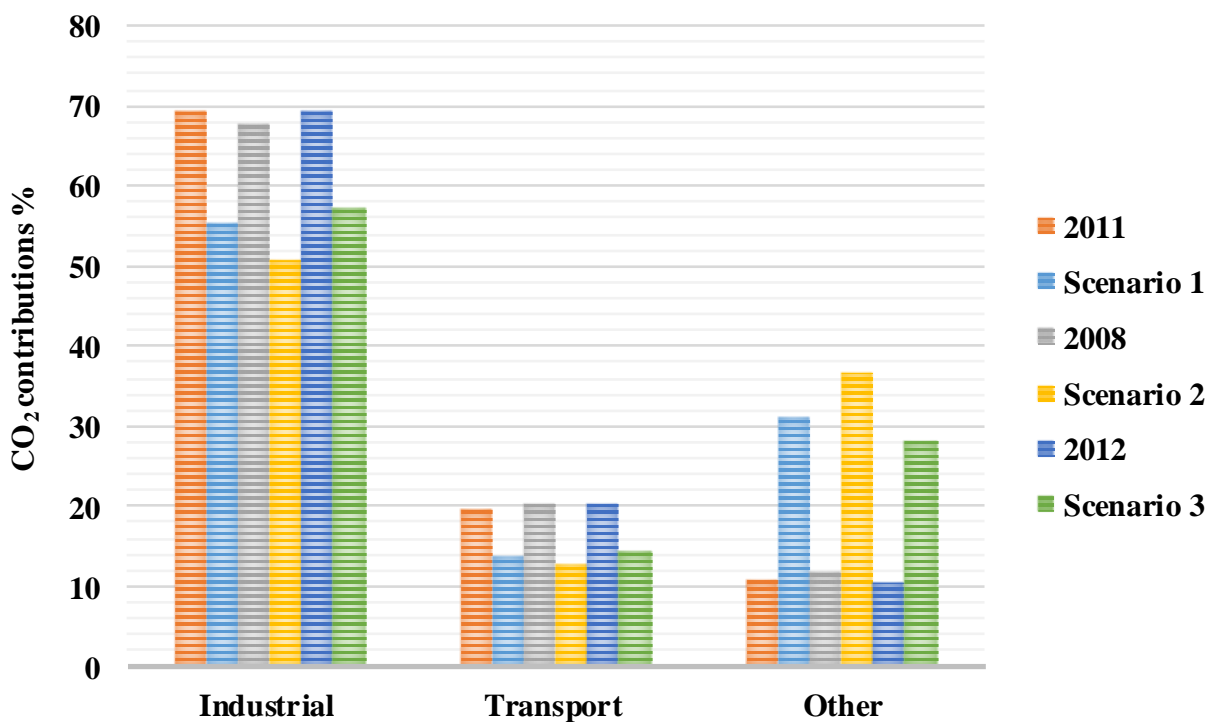

Fig. 6. Contributions in $\mathrm{CO}_{2}$ emission for various years and for three scenarios.

\section{ACKNOWLEDGMENTS}

This paper was a part of the project funded by Icelandic Research Fund (IRF), (in Icelandic: Rannsoknasjodur) and the grant number is 196458-051. Moreover, I would like to show my greatest appreciation to Dr. Movaffaq Kateb that Without his encouragement and useful guidance this paper would not have materialized.

\section{DISCLAIMER}

There is not any companies or specific commercial products.

\section{REFERENCES}

BBC (2020, 27 March). Will covid-19 have a lasting impact on the environment?, https://www.bbc.com/future/article /20200326-covid-19-the-impact-of-coronavirus-on-theenvironment

BioTechniques (2020, May 1). Predicting the course of a pandemic: When will COVID-19 end? https://www.biote chniques.com/coronavirus-news/news_predicting-the-cours e-of-a-pandemic-when-will-covid-19-end/

Boden, T.A., Marland, G. and Andres, R.J. (2009). Global, regional, and national fossil-fuel $\mathrm{CO}_{2}$ emissions. Carbon Dioxide Information Analysis Center, Oak Ridge National Laboratory, U.S. Department of Energy, Oak Ridge, Tenn., USA.

Energy Information Administration (EIA) (2016). Industrial sector energy consumption. In International energy outlook 2016, U.S. Energy Information Administration.

Energy Information Administration (EIA) (2019, June 4). How much carbon dioxide is produced when different fuels are burned? https://www.eia.gov/tools/faqs/faq.php ?id $=73 \& \mathrm{t}=11$

Energy Information Administration (EIA) (2020, February 20). How much carbon dioxide is produced per kilowatthour of U.S. electricity generation? https://www. eia.gov/tools/faqs/faq.php?id=74\&t=11

EnergyPost (2019, October 18). An independent global energy forecast to 2050 (part 3 of 5): Fossil fuels. https://energypost.eu/an-independent-global-energy-fore cast-to-2050-part-3-of-5-fossil-fuels/

GreenCarCongress (2014, July 28). Navigant forecasts global road transportation energy consumption to increase $25 \%$ by 2035; $84 \%$ from conventional fuels. https://www.gree ncarcongress.com/2014/07/20140728-navigant.html

Hansen, J., Johnson, D., Lacis, A., Lebedeff, S., Lee, P., Rind, D. and Russell, G. (1981). Climate impact of increasing atmospheric carbon dioxide. Science 213: 957-966. https://doi.org/10.1126/science.213.4511.957

IPCC (2007). Climate change 2007: Synthesis report. Contribution of Working Groups I, II and III to the Fourth Assessment Report of the Intergovernmental Panel on Climate Change, Core Writing Team, Pachauri, R.K and Reisinger, A. (Eds.), IPCC, pp. 95-212.

IPCC (2013). Technical Summary. In Climate Change 2013: The Physical Science Basis. Contribution of Working Group I to the Fifth Assessment Report of the Intergovernmental Panel on Climate Change, Stocker, T.F., Qin, D., Plattner, G.K., Tignor, M., Allen, S.K., Boschung, J., Nauels, A., Xia, Y., Bex, V. and Midgley, P.M. (Eds.), Cambridge University Press, pp. 33-115.

Knoema (2017). Jet fuel consumption in the world. https://knoema.com/data/consumption+jet-fuel

Krum, R. (2019). World GHG (green house gasses) emissions flow chart. https://coolinfographics.com/blog/2010/9/30/ world-ghg-green-house-gasses-emissions-flow-chart.html

Kwon, E.H. (2017). The impact of human activities on $\mathrm{CO}_{2}$ emissions; evidence from the OECD countries and the EU members. Master of Science Thesis Stockholm, KTH Industrial Engineering and Management, Sweden.

Mearns, E. (2018, March 7). Global $\mathrm{CO}_{2}$ emissions forecast to 2100. http://euanmearns.com/global-co2-emissionsforecast-to-2100/ 
Ritchie, H. and Roser, M. (2019, December). $\mathrm{CO}_{2}$ and greenhouse gas emissions. https://ourworldindata.org/co2and-other-greenhouse-gas-emissions

RYSRADENERGY (2020, March 25). COVID-19 demand update: Oil seen down $4.9 \%$, jet fuel down $20 \%$, road fuel down $5.6 \%$ in 2020. https://www.rystadenergy.com/new sevents/news/press-releases/covid-19-demand-update-oilseen-down-4point9-jet-fuel-down-20-road-fuel-down5point6-in-2020/

Safarian, S., Sattari, S. and Hamidzadeh, Z. (2018). Sustainability assessment of biodiesel supply chain from various biomasses and conversion technologies. Biophys. Econ. Resour. Qual. 3: 6. https://doi.org/10.1007/s41247018-0039-2

Safarian, S., Sattari, S., Unnthorsson, R. and Hamidzadeh, Z. (2019). Prioritization of bioethanol production systems from agricultural and waste agricultural biomass using multi-criteria decision making. Biophys. Econ. Resour. Qual. 4: 4. https://doi.org/10.1007/s41247-019-0052-0 Shakun, J.D., Clark, P.U., He, F., Marcott, S.A., Mix, A.C., Liu, Z., Otto-Bliesner, B., Schmittner, A. and Bard, E. (2012). Global warming preceded by increasing carbon dioxide concentrations during the last deglaciation. Nature 484: 49-54. https://doi.org/10.1038/nature10915

Statisca (2020). Forecast for worldwide industrial energy consumption from 2018 to 2050, by fuel. https://www.st atista.com/statistics/263471/industrial-energy-consumpti on-worldwide/

Received for review, April 16, 2020

Revised, May 11, 2020

Accepted, May 13, 2020 